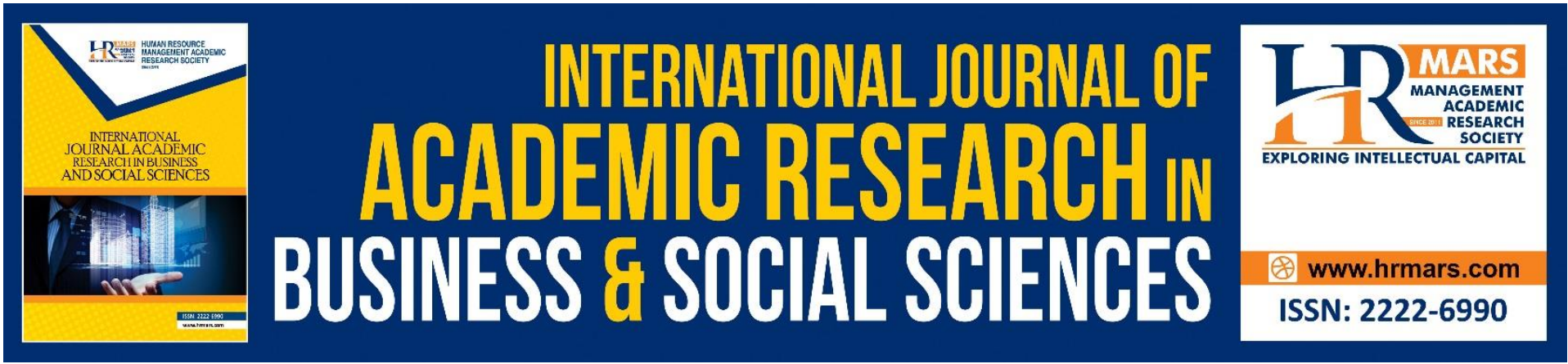

\title{
Counselling Intervention to Address School Bullying: A Systematic Review of Literature
}

\author{
Lai Wei Foon, Siti Aishah Hassan, Mohd Hamdan Mohamed Nordin
}

To Link this Article: http://dx.doi.org/10.6007/IJARBSS/v10-i16/8301

DOI:10.6007/IJARBSS/v10-i16/8301

Received: 14 September 2020, Revised: 11 October 2020, Accepted: 30 October 2020

Published Online: 23 November 2020

In-Text Citation: (Foon et al., 2020)

To Cite this Article: Foon, L. W., Hassan, S. A., \& Nordin, M. H. M. (2020). Counselling Intervention to Address School Bullying: A Systematic Review of Literature. International Journal of Academic Research in Business and Social Sciences, 10(11), 175-192.

\section{Copyright: (c) 2020 The Author(s)}

Published by Human Resource Management Academic Research Society (www.hrmars.com)

This article is published under the Creative Commons Attribution (CC BY 4.0) license. Anyone may reproduce, distribute, translate and create derivative works of this article (for both commercial and non-commercial purposes), subject to full attribution to the original publication and authors. The full terms of this license may be seen

at: http://creativecommons.org/licences/by/4.0/legalcode

Special Issue: Youth and Community Wellbeing: Issues, Challenges and Opportunities for Empowerment V2, 2020, Pg. 175 - 192

Full Terms \& Conditions of access and use can be found at http://hrmars.com/index.php/pages/detail/publication-ethics 


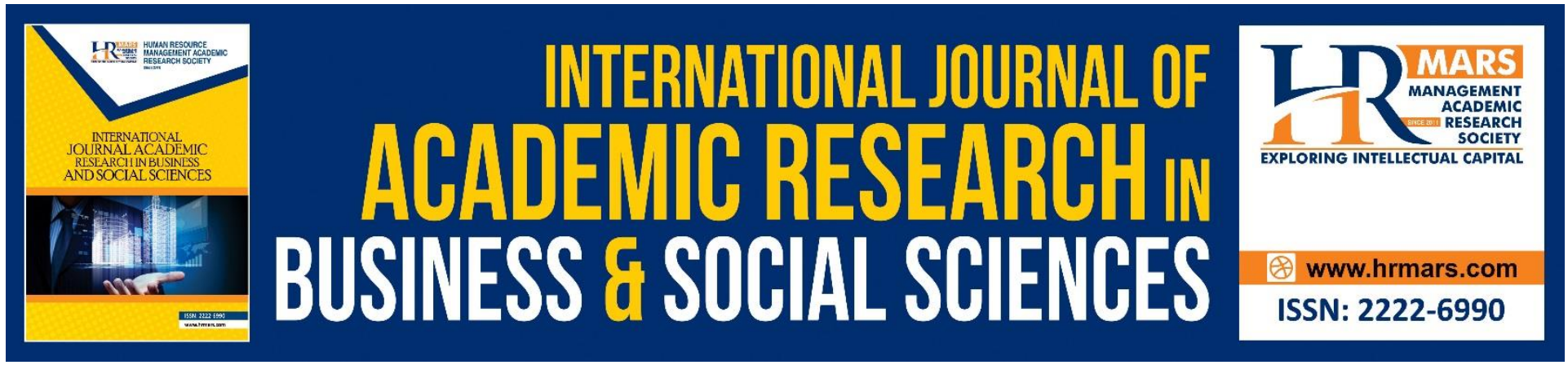

\title{
Counselling Intervention to Address School Bullying: A Systematic Review of Literature
}

\begin{abstract}
Lai Wei Foon
Institute for Social Science Studies, Universiti Putra Malaysia, Universiti Putra Malaysia, 43400 Serdang, Selangor, Malaysia, Department of Counsellor Education and Counselling Psychology, Faculty of Educational Studies, Universiti Putra Malaysia, Malaysia
\end{abstract}

Email: weifoon12@gmail.com

\section{Siti Aishah Hassan}

Institute for Social Science Studies, Universiti Putra Malaysia, Universiti Putra Malaysia, 43400 Serdang, Selangor, Malaysia, Department of Counselor Education and Counseling Psychology, Faculty of Educational Studies, Universiti Putra Malaysia, 43400 UPM Serdang, Selangor

Email: siti_aishahh@upm.edu.my

\section{Mohd Hamdan Mohamed Nordin}

Institute for Social Science Studies, Universiti Putra Malaysia, Universiti Putra Malaysia, 43400 Serdang, Selangor, Malaysia, Department of Counselor Education and Counseling Psychology, Faculty of Educational Studies, Universiti Putra Malaysia, 43400 UPM Serdang, Selangor

Email: mohdhamdan.mpic@gmail.com

\begin{abstract}
Bullying is a significant concern to the society and in schools these days. Both bullies and victims are at risk for negative developmental outcomes. School counsellors are facing many challenges to identify the warning signs and subsequently to address them efficiently. There are empirical studies on school-based bullying prevention programs and specific counselling approach to attend to this phenomenon. However, mixed findings were found on the effectiveness of both approaches to address school bullying issues. Ten articles were selected to identify 1) The role of school bullying prevention program to counselling services, 2) the role of school counsellors and their challenges in addressing bullying and 3) students' response to the role of counsellor on bullying. Based on this review, the implications to multicultural counselling were also being discussed.
\end{abstract}

Keywords: Counselling, School Counsellors, School Bullying.

\section{Introduction}

Bullying is an aggressive behaviour that is intentional and involves an imbalance of power or strength (Olweus in Sudan, 2016). School bullying is defined as when a student is subject to direct and negative behaviour, repeated over a period of time, by another student or group of students (Olweus, in PowerElliot \& Harris, 2012). School bullying is likely to bring negative impact to the school climate as it will 
affect students' learning processes and subsequently cause unhealthy physical and mental development of the affected students.

Ministry of Education Malaysia revealed that there was a $14.5 \%$ increase of reported cases from 3,011 cases in 2015 to 3,448 cases in 2016. More than 14,000 cases were reported between 2012-2015 (The Star, 2017). National Human Rights Society Malaysia, HAKAM, released a report on bullying in Malaysia school on January 2018, stated that the bullying incidents has reached at alarming rate to be addressed urgently. It is reported that in the US, one in five students suffer from some form of school bullying (National Center for Education Studies NCES, 2018), which is highly worrying. Literatures also revealed that most countries, one way or another, are experiencing similar social impact and mental health issues among students due to school bullying (UNESCO, 2017; Zych, Farrington, Llorent \& Tofi, 2017). To help address this bullying phenomenon, collaboration measures from education departments, social welfare departments, counsellors' associations or even police is critical.

It has proven that the magnitude of bullying can produce grave effect that affects children mentally which can extend into their adulthood (HAKAM, 2018). School bullying has the capacity making students who are being bullied, isolate themselves from others, feel despair, lost of selfesteem, achieve poor academic performance, and eventually reluctant to go to school. There is an increasing suicide or contemplating suicide rate among teenagers and children in recent years due to bullying (The Star, 2018). For bullies, violent behaviours will intensified if they are not properly dealt with. Regardless of victims of bullies or bullies themselves, the negative ramifications are huge to the society.

Generally, bullying are categorized into four main types, which are physical bullying, verbal bullying, relational/social bullying (Olweus, 1994), and in recent years the prevalence of cyberbullying. For this review, the discussion will focus on physical, verbal and relational/social bullying in schools that occur with the presence of targeted students. Cyberbullying is intentionally omitted in this review, as it does not take place with the present of targeted students. Also it has become a bigger standalone discussion issue or construct by itself in recent years (Randa, Reyns, \& Noble, 2015; Wachs, Junger \& Sittichai, 2015). In defining school bullying stakeholders, three groups emerge as in bullying literatures including those who bully, the bystanders and the bullying

victims (Olweus, 1994; McCormac, 2014; Sudan, 2016; Antwi et al., 2014).

In order to handle this complicated phenomenon, special skills are required for an effective outcome. Thus, counsellors have been tasked and become the key driver to handle school bullying, as well as leader in implementation anti-bullying programs (Midgett, Doumas, Sears, Lundquist, \& Hausheer, 2015). Despite the urgency to address this phenomenon, certified counsellors with necessary anti-bullying training are extremely limited. Therefore, school counsellors are learning onthe-job to master the necessary skills while identifying appropriate prevention programs to be implemented in schools (American School Counsellor Association "ASCA", 2013; HAKAM, 2018). In Malaysia, there are no specific bullying prevention programs in place, most schools will apply own approach to counter their own bullying incidents (Haslee, Abdullah \& Nawi, 2018). In short, any bullying prevention programs that are currently in practice are designed by school authorities and/or counsellors themselves (2018).

It is reported and confirmed that majority of the bullying cases have gone unreported. Studies indicated that the victims have less trust with the counsellors or have not confident on the effectiveness of the school bullying prevention programs. Most importantly, it is the fear being retaliated later (McCormac, 2014; Hakam, 2018). This fear of repercussion needed to be countered in order to increase the students' confidence to report their cases. 
To enhance school authorities to address school bullying more effectively, many schools in the US and Europe, have adopted research-based bullying prevention programs such as OBBP - "Olweus Bullying Prevention Program"; STAC - "Stealing the show, Turning it over, Accompanying others and Coaching compassion" and STR - "Step for Respect to name a few (Olweus, 1993; Midgett, Doumas, Sears, Lundquist, \& Hausheer, 2015; Brown, Low, Smith, Haggerty, 2011). Literatures on the use of similar programs in Asian schools were not found during this review search.

When evidence-based prevention programs are implemented in schools, these programs provide steps that can help to empower counsellors to focus using their counselling skills for maximum outcomes. As counsellors are trained in empathic listening and relationship building with students, this will help facilitate bullying prevention programs' implementations more effectively (Power-Elliot \& Harris, 2012; Midgett, Doumas \& Johnston, 2017). This is because school counsellors are trained to help in students' behaviour, emotions and cognition while tasked to support a safe learning environment (ASCA, 2003). School counsellors do not and cannot work alone to address school bullying. To produce effective anti-bullying results, they have to take a leading role to form collaboration with relevant school stakeholders such as principals, district administrators, teachers, parents to identify appropriate bullying prevention program for the welfare of the students. However, empirical studies in counselling intervention or counsellors' roles on school bullying are rather limited as compared to studies on teachers' participation in school bullying (McComac, 2014; Austin, Reynolds \& Barnes, 2016).

\section{Objectives}

The focus of this systematic review is to identify areas that can empower counsellors to address school bullying while looking into their challenges in carrying out their roles and duties pertaining to school bullying. Many times, counselling services are often seen as the best, if not the ultimate choice to help address school bullying (Austin, Reynolds \& Barnes, 2012). Counsellors are also perceived to take leadership role in forming collaboration with school stakeholders to identify and implement effective bullying prevention programs (Austin, Reynolds \& Barnes, 2016; Midgett, Doumas \& Johnston, 2017). As school environment is evolving with the prevalence and influence of social media, counsellors are encountering new bullying behaviours and acts that students learn from the cyber world. Therefore, any interventions and counselling skills have to be scalable and appropriate to solve bullying issues. The objectives for this review are:-

1) To determine the association of counselling services using bullying prevention programs to address bullying

2) To find out counsellors' opinions on their roles and challenges in school bullying programs

3) To find out students' response on the role of counsellors in addressing bullying

\section{Method}

\section{Search Procedure}

The objectives serve as the guidelines to filter relevant articles for the search. This review was conducted on both qualitative and quantitative related articles adopting Preferred Reporting Items for systematic reviews and Meta-Analyses criteria (Moher, Liberati, Tetzlaff, Altman, \& PRISMA Group, 2009). Articles were retrieved from SCOPUS, Wiley, Ebscohost and Google Scholar databases.

The search started with keywords of a) counselling, b) counsellors, c) school bullying, and d) interventions. The second filtration limits to abstracts and journals that were related to teachers, school psychologists, schools or universities, and preventions. The number of literatures found was 
high but the relevancy of literatures that related to counselling on bullying for the latest five year were very limited, thus the search was extended to 2012.

The step-by-step selection process is shown in Figure 1. The initial search on keyword terms produced 1,850 articles. To retrieve more relevant articles, further filtration was conducted on journals that covered the terms of teachers, school psychologists, elementary/middle and high schools, bullying preventions and strategies. Exclusion criteria on duplicated articles, cyberbullying articles, review articles, books \& chapters, non-counselling articles, and full text assess reduced the number to 17 and 10 literatures were selected for this review.

\section{Findings}

In order to present a clear overview of the 10 selected literatures that explore counselling interventions to address school bullying, a summary of table was prepared. The table is in the order of author/year, title of the literature, country, journal title, participants of the study, study design and findings highlights as in Table 1.

The reviewer attempted to include as many countries of origins of the selected literatures for this review with the intention to see possible differences in findings. Out of the 10 studies, 6 were from USA, 1 from Australia, Ireland, Jordan, Turkey and UK respectively. Reviewer also attempted to include cases from Malaysia. However, literatures on quantitative research was limited and most focused on qualitative studies.

Two of the selected quantitative literatures were using T-test as design method, and the rest of the studies were skewed to quantifiable questionnaires, interviews and observations studies. All studies were conducted in schools premises except 3 studies that were web-based.

Selected studies involved samples participants from students, counsellors, school psychologists and disciplinary teacher. Except web-based questionnaires, all studies were conducted in schools premises and administered either by assigned counsellors and the authors themselves. 


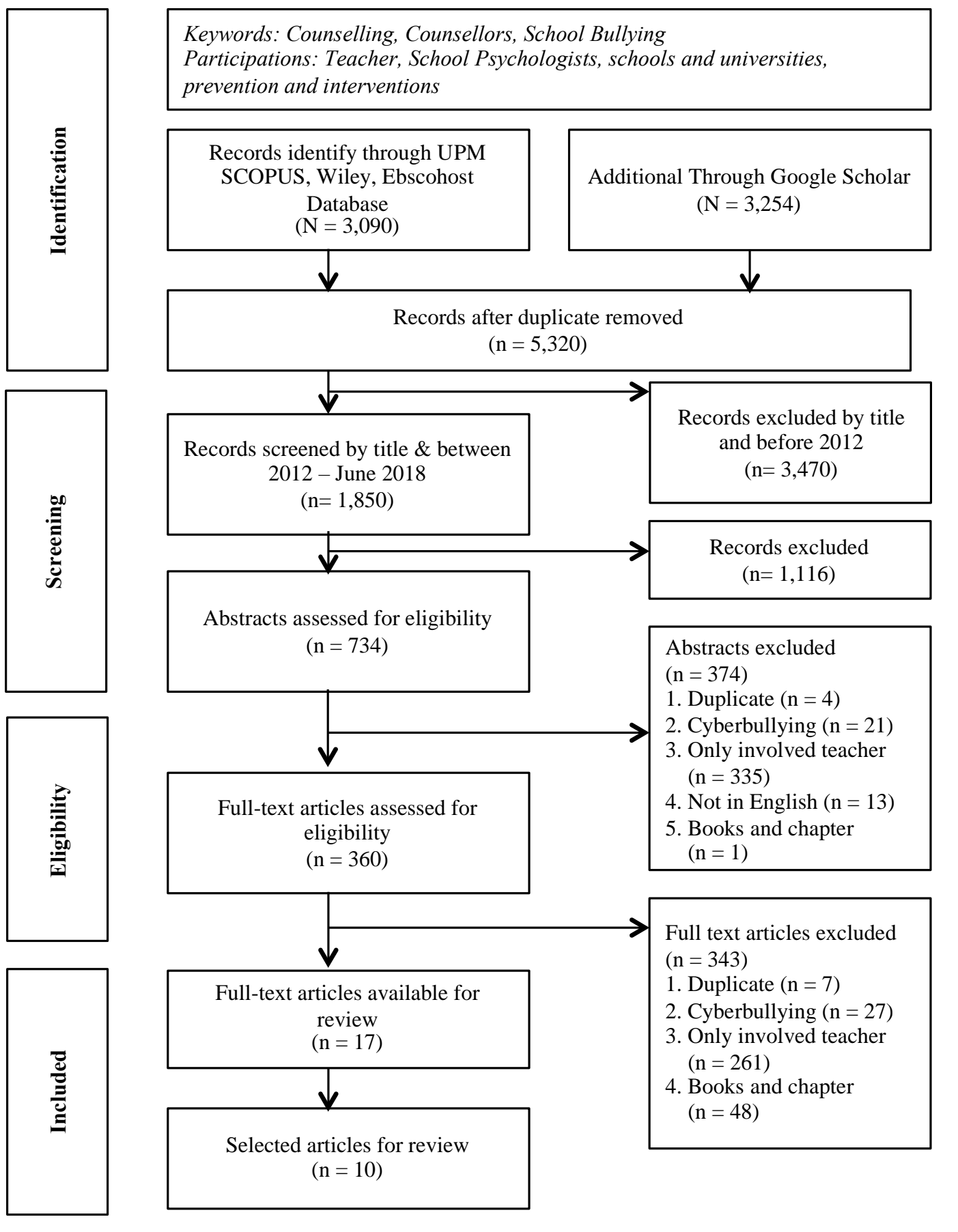

Figure 1. Flow diagram for selection review of studies on Counselling to Address School Bullying 
Table 1. Summary of studies characteristics

\begin{tabular}{|c|c|c|c|c|c|c|}
\hline AUTHOR/YEAR & TITLE & COUNTRY & JOURNAL & $\begin{array}{l}\text { PARTICIPANTS } \\
\text { OF STUDY }\end{array}$ & STUDY DESIGN & FINDINGS HIGHLIGHTS \\
\hline $\begin{array}{l}\text { Acuri, M. N. } \\
\text { (2018) }\end{array}$ & $\begin{array}{l}\text { Counselling } \\
\text { Relationship } \\
\text { Experiences for K-12 } \\
\text { school counsellors } \\
\text { who also fulfilled the } \\
\text { role of anti-bullying } \\
\text { specialist }\end{array}$ & USA & $\begin{array}{l}\text { Journal of } \\
\text { School } \\
\text { Counselling }\end{array}$ & $\begin{array}{l}12 \text { counsellors } \\
\text { who is also anti- } \\
\text { bullying specialist } \\
\text { from elementary, } \\
\text { middle and high } \\
\text { schools }\end{array}$ & $\begin{array}{l}\text { Questionnaires and } \\
\text { interviews by } \\
\text { counsellors }\end{array}$ & $\begin{array}{l}\text { - Counsellors felt under great pressure } \\
\text { with dual role } \\
\text { - Relationship with students was } \\
\text { compromised as one deal with } \\
\text { feeling and anti-bullying deals with } \\
\text { facts }\end{array}$ \\
\hline $\begin{array}{l}\text { Cornell, D. \& } \\
\text { Huang, F. } \\
(2014)\end{array}$ & $\begin{array}{l}\text { Identify victims of } \\
\text { bullying: Use of } \\
\text { counsellors' } \\
\text { interview to confirm } \\
\text { peers nomination }\end{array}$ & USA & $\begin{array}{l}\text { Professional } \\
\text { School } \\
\text { Counselling }\end{array}$ & $\begin{array}{l}7,889 \quad \text { students } \\
\text { (grade } 3-12 \text { ) }\end{array}$ & $\begin{array}{l}\text { Questionnaires } \\
\text { swith vignette by } \\
\text { counsellors }\end{array}$ & $\begin{array}{l}\text { - Safe report system was crucial to } \\
\text { encourage reporting } \\
\text { - Counsellors with anti-bullying } \\
\text { training identify victims more } \\
\text { effectively }\end{array}$ \\
\hline $\begin{array}{l}\text { Didaskalou, E., } \\
\text { Skrzypiec, G., } \\
\text { Andreou, E., \& } \\
\text { Slee, P. (2017) }\end{array}$ & $\begin{array}{l}\text { Taking action against } \\
\text { victimization: } \\
\text { Australia middle } \\
\text { school students' } \\
\text { experience }\end{array}$ & Australia & $\begin{array}{l}\text { Journal of } \\
\text { Psychologist } \\
\mathrm{s} \text { and } \\
\text { Counsellors } \\
\text { in School }\end{array}$ & $\begin{array}{l}171 \text { middle school } \\
\text { students }\end{array}$ & $\begin{array}{l}\text { Questionnaires and } \\
\text { interview } \\
\text { conducted by } \\
\text { counsellors }\end{array}$ & $\begin{array}{l}\text { - Counselling help was not much } \\
\text { sought after as help to the victims } \\
\text { - Students were receptive to anti- } \\
\text { bullying strategies if well taught } \\
\text { - Increase awareness on bullying } \\
\text { prevention programs to students }\end{array}$ \\
\hline
\end{tabular}




\begin{tabular}{|c|c|c|c|c|c|c|}
\hline $\begin{array}{l}\text { Lund, M. E., } \\
\text { Blake, J. J., } \\
\text { Ewing, K, H., \& } \\
\text { Banks, S.C. } \\
\begin{array}{l}(2012)\end{array}\end{array}$ & $\begin{array}{l}\text { School Counsellors' } \\
\text { and School } \\
\text { Psychologists' } \\
\text { Bullying Prevention } \\
\text { and Intervention } \\
\text { Strategies: A Look } \\
\text { Into Real-World } \\
\text { Practices }\end{array}$ & USA & $\begin{array}{l}\text { Journal of } \\
\text { School } \\
\text { Violence }\end{array}$ & $\begin{array}{l}560 \text { school } \\
\text { counsellors and } \\
\text { psychologists }\end{array}$ & $\begin{array}{l}\text { Web-based } \\
\text { questionnaires } \\
\text { survey }\end{array}$ & $\begin{array}{l}\text { - Evidence-based bullying prevention } \\
\text { program required modification to } \\
\text { suit each school's needs } \\
\text { - More effective intervention if } \\
\text { programs were designed by } \\
\text { counsellors' understanding and } \\
\text { knowledge of school's needs }\end{array}$ \\
\hline $\begin{array}{l}\text { McCormac, E. M. } \\
(2014)\end{array}$ & $\begin{array}{lr}\text { An } & \text { elementary } \\
\text { school's } & 4-y e a r \\
\text { journey: Preventing } \\
\text { and Responding to } \\
\text { Bullying }\end{array}$ & USA & $\begin{array}{l}\text { Professional } \\
\text { School } \\
\text { Counselling }\end{array}$ & $\begin{array}{l}299 \text { upper grades } \\
\text { elementary } \\
\text { students and } 36 \\
\text { teachers }\end{array}$ & $\begin{array}{l}\text { Questionnaires } \\
\text { survey in school } \\
\text { conducted } \\
\text { counsellors }\end{array}$ & $\begin{array}{l}\text { - School counsellors were the most } \\
\text { suitable person to decide } \\
\text { appropriate bullying prevention } \\
\text { program } \\
\text { - Driver of collaboration with school } \\
\text { stakeholders; prevention process } \\
\text { and promotion of anti-bullying } \\
\text { campaign }\end{array}$ \\
\hline $\begin{array}{l}\text { Midgett, A., } \\
\text { Doumas, D.M., \& } \\
\text { Johnston, A.D. } \\
\text { (2017) }\end{array}$ & $\begin{array}{l}\text { Establishing School } \\
\text { Counsellors as } \\
\text { Leaders in } \\
\text { Bullying Curriculum } \\
\text { Delivery: Evaluation } \\
\text { of a Brief, School- }\end{array}$ & USA & $\begin{array}{l}\text { Professional } \\
\text { School } \\
\text { Counselling }\end{array}$ & $\begin{array}{l}144 \text { students on } \\
\text { their response to } \\
\text { STAC program }\end{array}$ & $\begin{array}{l}\text { Single-group T-test } \\
\text { with baseline, post } \\
\text { training and 4- } \\
\text { month follow up } \\
\text { survey conducted } \\
\text { by counsellors }\end{array}$ & $\begin{array}{l}\text { - Effective in reducing bullying cases } \\
\text { - Students were receptive to program } \\
\text { only when "trained" and understood } \\
\text { - Higher effectiveness if trained within } \\
\text { normal classroom schedule }\end{array}$ \\
\hline
\end{tabular}




\begin{tabular}{|c|c|c|c|c|c|c|}
\hline & $\begin{array}{l}\text { Wide Bystander } \\
\text { Intervention }\end{array}$ & & & & & \\
\hline $\begin{array}{l}\text { Power-Elliott, } \\
\text { M. \& Harris, E. } \\
\text { G. } \\
(2012)\end{array}$ & $\begin{array}{l}\text { Guidance counsellor } \\
\text { strategies of } \\
\text { handling bullying }\end{array}$ & UK & $\begin{array}{l}\text { British } \\
\text { Journal of } \\
\text { Guidance } \\
\text { and } \\
\text { Counselling }\end{array}$ & 94 counsellors & $\begin{array}{l}\text { Web based } \\
\text { questionnaires }\end{array}$ & $\begin{array}{l}\text { - Non-judgmental to all bullying } \\
\text { stakeholders were important } \\
\text { - Dual role as disciplinarian will } \\
\text { compromise trust with students }\end{array}$ \\
\hline $\begin{array}{l}\text { McElearney, A., } \\
\text { Adamson, } \\
\text { Shevlin, M., } \\
\begin{array}{l}\text { Bunting, } \\
(2012)\end{array}\end{array}$ & $\begin{array}{l}\text { Impact Evaluation of } \\
\text { a School-based } \\
\text { Counselling } \\
\text { Intervention in } \\
\text { Northern } \\
\text { Ireland: Is it Effective } \\
\text { for Pupils Who } \\
\text { Have Been Bullied? }\end{array}$ & Ireland & $\begin{array}{l}\text { Child Care in } \\
\text { Practice }\end{array}$ & 202 students & $\begin{array}{l}\text { Questionnaires } \\
\text { conducted by } \\
\text { counsellors }\end{array}$ & $\begin{array}{l}\text { - Counselling is an effective } \\
\text { intervention to help bullied students } \\
\text { - Counselling is a key component to } \\
\text { drive effective school bullying } \\
\text { prevention to address the issue }\end{array}$ \\
\hline $\begin{array}{l}\text { Tawalbeh, H. A., } \\
\text { Abueita, D. J., } \\
\text { Mahasneh, A., } \\
\text { Shammout, N. } \\
\text { (2015) }\end{array}$ & $\begin{array}{l}\text { Effectiveness of a } \\
\text { Counselling Program } \\
\text { to improve Self } \\
\text { Concept } \quad \text { and }\end{array}$ & Jordan & $\begin{array}{l}\text { Review of } \\
\text { European } \\
\text { Studies }\end{array}$ & $\begin{array}{l}20 \text { males sixth } \\
\text { graders }\end{array}$ & $\begin{array}{l}\text { Using T-test to } \\
\text { assess Self-Concept } \\
\text { Scale and Bully } \\
\text { Behaviour Scale - }\end{array}$ & $\begin{array}{l}\text { - Evidence that counsellors helped in } \\
\text { increasing self-concept of bully } \\
\text { victims }\end{array}$ \\
\hline
\end{tabular}


INTERNATIONAL JOURNAL OF ACADEMIC RESEARCH IN BUSINESS AND SOCIAL SCIENCES

Vol. 10, No. 16, Youth and Community Wellbeing: Issues, Challenges and Opportunities for Empowerment V2. 2020, E-ISSN: 2222-6990 @ 2020 HRMARS

\begin{tabular}{|c|c|c|c|c|c|c|}
\hline & $\begin{array}{l}\text { Achievement in } \\
\text { Bully-victims }\end{array}$ & & & & $\begin{array}{l}\text { administered by } \\
\text { counsellors }\end{array}$ & $\begin{array}{l}\text { - Counselling provided security and } \\
\text { alleviated feeling of isolation }\end{array}$ \\
\hline $\begin{array}{l}\text { Uzunboylu, H., } \\
\text { Baglama, b., } \\
\text { Ozer, N., } \\
\text { Kucuktamer, T. } \\
\text { \& Kuimova V, M. } \\
\text { (2017) }\end{array}$ & $\begin{array}{l}\text { Opinion of school } \\
\text { counsellors about } \\
\text { bullying in Turkish } \\
\text { high school }\end{array}$ & Turkish & $\begin{array}{l}\text { Social } \\
\text { Behaviour } \\
\text { and } \\
\text { Personality }\end{array}$ & $\begin{array}{l}25 \text { school } \\
\text { counsellors }\end{array}$ & $\begin{array}{l}\text { Questionnaires and } \\
\text { interviews } \\
\text { conducted by } \\
\text { counsellors }\end{array}$ & $\begin{array}{l}\text { - Lack of safety precaution in current } \\
\text { action plans } \\
\text { - Counsellors take more responsibility } \\
\text { to lead and implement }\end{array}$ \\
\hline
\end{tabular}


INTERNATIONAL JOURNAL OF ACADEMIC RESEARCH IN BUSINESS AND SOCIAL SCIENCES

Vol. 10, No. 16, Youth and Community Wellbeing: Issues, Challenges and Opportunities for Empowerment V2. 2020, E-ISSN: 2222-6990 @) 2020 HRMARS

\section{Discussion}

\section{Association of counselling intervention using bullying prevention programs to address bullying}

Two studies were specifically using evidence-based bullying interventions program namely STAC and STR (McCormac, 2014; Midgett, Doumas \& Johnston, 2018) as test for counselling effectiveness. Both studies indicated that these research-based programs, proved their effectiveness in reducing bullying cases after implementation. Both studies indicated that the research-based programs serve as good guidelines and procedures that could enhance counsellors' role in their bullying prevention counselling services. However, Cornell and Huang (2014) argued that bullying prevention programs might require certain modifications to fit into local schools' needs for higher effectiveness. Lund et al. (2012) were concerns that standard school-based programs that were assigned by district government or school authorities were too universally oriented, thus might not be able to address each school's bullying issues and needs. It is admitted that some school-based programs were difficult to implement as admittedly by developers themselves without proper training (Midgett, Doumas \& Johnston, 2018).

Despite effectiveness of school-based bullying prevention programs has been substantiated with evidence, it is with the condition proper training has been given to school counsellors and accessibility by students is made easy (McElearney, Adamson, Shevlin \& Bunting, 2012; Didaskalou, Skrzypiec, Andreou, \& Slee, 2017)). Therefore, comprehensive training is crucial for effective outcomes. Also, school counsellors were encourage to modify the programs, within accepted level, in accordance to school's requirements (McCormac, 2014). This is because a modified bullying prevention programs that adapt to schools' needs are likely to produce more positive outcomes. Counsellors were also encouraged to design own bullying prevention programs, as there would be more responsive to school bullying phenomena (Lund, et al., 2012). This is because school counsellors take into considerations school environments, peers reviews and their relationship with the targeted students As such, bullying issues could be addressed more effectively based on school climates. Overall, bullying prevention programs that meet the needs of individual school help counsellors to address bullying issues more efficiently and effectively.

Studies also indicated that schools authorities play a crucial role in driving and reinforcing the implementation and intervention of bullying prevention program. (Power-Elliot \& Harris, 2012; Lund, et al., 2012; McCormac, 2014; Midgett, Doumas \& Johnston, 2017). Continuous commitment from school authorities in holistic manners, decide the success of counsellors' intervention to bullying prevention programs.

School counsellors can push for awareness campaigns to the school community regularly. It is reported that awareness on bullying prevention programs was not high among students, as some schools did not view anti-bullying as a legitimate issue that require attention and intervention (McCormac, 2014). McElearney, et al. (2012) emphasized that students must be encouraged to access and respond to school bullying prevention program. It is very important to raise the awareness in entire school community through seminars and campaigns. These campaigns not only targeted to students but also to teachers (McCormac, 2014; Uzunboylu, Ozer, Kucuktamer, \& Kuimova, 2017).

As teacher spend most times with their students, that is extremely important to include teachers in school bullying prevention program to drive the success of the programs (McCormac, 2014). Teachers can be trained to be more sensitive to identify bullied victims, bullies or bystanders among their students for counselling. Besides bullying prevention related campaigns, it is beneficial 
INTERNATIONAL JOURNAL OF ACADEMIC RESEARCH IN BUSINESS AND SOCIAL SCIENCES

Vol. 10, No. 16, Youth and Community Wellbeing: Issues, Challenges and Opportunities for Empowerment V2. 2020, E-ISSN: 2222-6990 @ 2020 HRMARS

to increase education on self-respect and cultivating good values, respecting others' rights should also be constantly propagated to instill positive behaviour among students, which Malaysian schools are doing.

School counsellors had common response that bullying prevention programs in general were lack of safety precaution to protect those who reported bullying cases (McCormac, 2014; Power-Elliot \& Harris, 2012; Uzunboylu et al., 2017). Students especially the victims and bystanders of bullying were fear of being retaliated if their reported their cases to the school. School counsellors believed that safe reporting process must be included to safeguard and protect these groups of students (Cornell \& Huang, 2014; Tawalbeh, Abueita, Mahasneh, Shammout, 2015). The stigma of reporting bullying cases will continue to remain high across all cultures if no safe reporting system was assured and put in place. Schools' emphasis to safeguard involved students will certainly help to encourage more bullying reports made.

\section{Counsellors' Opinions on their Roles and Challenges in School Bullying Interventions}

Roles: These studies co-incidentally showed a few common findings on the roles of school counsellors. Firstly, school counsellors were aware that they play critical role in driving prevention and resolution of school bullying (Power-Elliot \& Harris, 2012; Tawalbehet et al., 2015; Uzunboylu et al., 2017). However, most admitted that they were not trained formally in managing school bullying (Acuri, 2018; Cornell \& Huang, 2014). In US, school counsellors were automatically tasked to handle bullying issue as anti-bullying specialists even without adequate trainings (Acuri, 2018). This has added pressure to school counsellors to be competence not only in regular counselling duties, by default were expected to excel in a highly challenging specialty area i.e. bullying. In order to qualify as a counsellor/anti-bullying specialist, school counsellors have to pay, on their own, to attend these courses (ASCA, 2013). Unless the course are sponsored by school authorities, the voluntarily participation to anti-bullying courses is rather remote.

Secondly, school counsellors were perceived to be the major driver for effective bullying prevention programs (Lund, et al., 2012; Acuri, 2018). Effective bullying prevention programs requires school counsellors to initiate collaboration and work with all school stakeholders for support such as principals, teachers, administrators, disciplinary teachers and all school staff. School counsellors have to ensure the bullying prevention programs were fully understood and supported by all parties regardless of ethnicity, race and school settings (Power-Elliot \& Harris, 2012; McCormac, 2014).

Thirdly, school counsellors' were responsible educating parents to understand bullying problems. The aim was to be more sensitive to identify the signs of bullying from their children's behaviour (McCormac, 2014; Acuri, 2018). By this collaboration, bullying behaviour can be addressed and managed at early stages. Besides, school counsellors have the responsibilities to promote bullying prevention campaigns and introduce them to students within classroom schedules regularly (Tawalbehet al., 2015; Midgett, Doumas \& Johnston, 2017).

Last but not least, counsellors' attitude towards school climate has direct relation against the outcome to the bullying incidents. Counsellors who are more enthusiastic into bullying prevention programs will likely to offer counselling, enlist other adults for help whenever necessary. The enlist adults include school principals, staff and parents whom can help in reinforcing higher effectiveness (Power-Elliot \& Harris, 2012). The holistic collaboration will enhance the bullying issues to be addressed in consensus manner based on the severity of the incidents. 
INTERNATIONAL JOURNAL OF ACADEMIC RESEARCH IN BUSINESS AND SOCIAL SCIENCES

Vol. 10, No. 16, Youth and Community Wellbeing: Issues, Challenges and Opportunities for Empowerment V2. 2020, E-ISSN: 2222-6990 @ 2020 HRMARS

School counsellors were reported that they are always in conflict especially requested by school authorities to implement some form of punishment to bullies that show aggression. School counsellors are against punishment and sanction-imposed in their profession. Punitive measures were not seen as effective intervention strategies to solve bullying issues (Power-Elliot \& Harris, 2012; Cornell \& Harris, 2014).

Challenges: School counsellors had limited control over school-based bullying prevention programs that were decided by district government. These programs may not be appropriate for their school climates and environments (Lund, et al., 2012; McCormac, 2014). As school-based programs maybe standard model such as OBBP or STR, counsellors' professional input and knowledge of the school climate were not taken into consideration. Also, counsellors have to undergo training on schoolbased prevention program in order to implement them correctly and effectively (Lund et al., 2012, McCormac, 2014; Acuri, 2018). For now, training in bullying prevention program and its skills were perceived to be inadequate for counsellors' preparedness.

In addition to that, counsellors' dual roles in schools had somewhat compromised their services (Cornell \& Huang, 2014; Midgett, Doumas \& Johnston, 2017). Power-Elliot \& Harris (2012) found out those school counsellors who also act as disciplinarian faced ethical dilemma. While counsellors opt for solving bullying problem emphatically; disciplinarian may choose to impose punishment to resolve bullying issues. School counsellors who were also anti-bullying specialist also faced similar dilemma, as one dealt with emotion and feelings and the latter dealt with facts (Cornell \& Huang, 2014). Due to the dual roles in schools, trust from students towards counsellors obviously decreased as students were confused if the sharing during counselling session would be used to reprimanded them when counsellor played the disciplinarian role or anti-bullying specialists' role.

Students' response on the role of counsellors in addressing bullying: Students were not aware of school bullying intervention programs and perceived these programs were unlikely to be beneficial to them (McCormac, 2014). Studies found that victims did not feel safe to report this to school as they maybe further retaliated by the bullies (2014). The affected students had less trust on the competence of counsellors, did not think they can solve their issues. Stigma of refusal to seek counselling in general, further added to a low-reported bullying cases.

However, receptive level to these bullying prevention programs was high once the students were exposed and taught to these strategies that they know will equip them with skills for handling bullying (Didaskalou, Skrzypiec, Andreou, \& Slee, 2017). The major challenge for counsellors or schools is to encourage the affected students to come forward, then teach them the assertive skills and provide continuous support them throughout their battling journey.

In order to gather more bullying report cases, suggestion has been made to use bystanders, who are witness to bullying cases, to help identify the affected students (Cornell \& Huang, 2014; Midgett, Doumas \& Johnston, 2017). This process will allow counsellors pro-actively approach the victims for counselling intervention. This process also displays a caring role that the school authorities play that they are concerned about their students' well-being. With the hope that trusts on counsellors and bullying prevention programs increased amongst the students (2017).

Tawalbehet et al. (2015) indicated that self-concept and self-confidence of targeted students had improved after counselling intervention. The study specifically emphasized that this can only be 
INTERNATIONAL JOURNAL OF ACADEMIC RESEARCH IN BUSINESS AND SOCIAL SCIENCES

Vol. 10, No. 16, Youth and Community Wellbeing: Issues, Challenges and Opportunities for Empowerment V2. 2020, E-ISSN: 2222-6990 @) 2020 HRMARS

achieved when counsellors show they are reliable to be trusted. However, the study pointed out that attention and care from counsellors contributed more to the improvement in self-confidence and self-assertiveness compared to bullying prevention programs.

The students also found that group counselling helped in alleviate their feelings of isolation more effectively (Lund, et al., 2012; Cornell \& Huang, 2014; Tawalbehet et al., 2015). In group counselling, the support from one another helped them to increase their self-confidence and selfworth. From counsellors' perspectives, group counselling was highly preferred and more effective outcome could be achieved (Tawalbehet et al., 2015).

\section{Limitation}

The limitation of this review is 7 out of 10 articles were from US and Europe. The findings were western culture inclined and with more mature bullying intervention programs and counselling services in place. Regional cultural factors may also influence the outcomes of these findings. Thus, this review cannot be generalized universally. Articles on evidence-based prevention programs were by the developers themselves thus may warrant further discussions from other authors (as third parties) to validate its reliability and effectiveness.

Design methods such as web-based questionnaires could be less accurate as respondents may provide answer half-heartedly at time of submission as compare to those administered by counsellors. Studies that encompassed different schools, different location or countries, studied periods and sample sizes may result in response bias.

\section{Implications and Future Research}

With prevalence of bullying in most countries, the role of school counsellors are increasingly important to address this phenomena for a safe and healthy school climate. Literatures have revealed that school counsellor should be the leader in addressing school bullying especially counselling intervention has been proven effective in addressing school bullying. While teachers and counsellors attempt to identify bullying targets, a lot still needs to be done to encourage bullying affected students, especially victims, to come forward and seek school professional help. The stigma to meet counsellors need to be broken for effective bullying prevention intervention. Deteriorating academic performance, poor school attendance or to the extreme of self-harm will occur, if bullying is not addressed timely and effectively.

Further research is needed to explore how training can be effectively given on bullying prevention techniques, as this review reported that inadequate training in this area for counsellors. Another area that requires further studies will be the adaptability and scalability of a bullying prevention programs for different cultures, race or ethnicity, religion belief, and gender. In short, the content of the bullying prevention program should be further be localized, tested for its validity and reliability across all cultures so as the designs are fit-to-use in diversified community of races and cultures.

These future findings based on diversification of cultural backgrounds will empower school counsellors from different countries and background to apply the relevancy into their practice and their cultures. It also serves as guidelines or reference for school counsellors when handle and manage bullying students such as in Malaysia. 


\section{Conclusion}

Bullying is a pervasive issue that affects our students today and it should not be taken lightly. Schoolbased bullying prevention programs are believed could empower school counsellors to address the school bullying issues, with the condition of comprehensive trainings is given. School-based bullying programs allow school counsellor to focus their skill and effort to perfect the intervention process with necessary modification according to schools' needs.

Working together with teachers is important for school counsellors, to drive the bullying prevention programs and also awareness campaigns in schools. It is believed that effective will increase as teachers can associate with students well with their characters and behaviour as they spend most time with their students. Pushing for support and commitment from school stakeholders such as principals, school administers and parents will determine higher chances of effective outcomes of the bullying prevention programs.

School counsellors felt in increasing pressure when they are bestowed with more responsibilities. They are tasked to manage a challenging society issue with high expectation from school authorities and parents. Besides, they have to try to make the prevention programs a success, organize awareness activities and campaigns, collaborate with various stakeholders, encourage students to come forward and attend to cases personally are strenuous if without help and support.

From students' perspective, many students are not aware of school's bullying prevention programs and found no confidence in the interventions too. Therefore, making students feel safe to report their bullying cases and not be retaliated later is important. Therefore, safety measure of the reporting process will encourage not only bully victims but also bystanders to come forward without hesitation. While students are encourage to come forward, they should always be reminded that they have continuous support from school to be assertive and handle bullying.

A successful bullying prevention will require a strong bullying prevention programs, commitment from school stakeholders, effort and skills from school counsellors to help these group of bullying group to have a healthier physical and mental development.

\section{Implication on Multicultural Counselling}

School-based bullying prevention programs especially that are assigned by district or central government should be tested and validated for its content to ensure it is appropriate to be implemented and cater for diversified cultures, different faiths, gender, age and ethnicity or race in order to produce positive outcomes. For example, does the program is fit to be apply in religion schools or does the program is appropriate to be conducted for primary schools or secondary schools? These are some examples that can influence the effectiveness of a program.

Counselling approach to address bullying should take into consideration of individualistic and collectivistic of the society. Considering family and cultural pressure in decision is important in a collectivistic society such as Malaysia. One of the reasons that reported bullying cases were low is due to embarrassment that will cause to the family - that he or she is a coward thus being bullied as reported in Malay Mail (Suppayah, 2016). There are cases in Malaysia reported that parents were less assertive in managing bullying issues and tend to "brush off" the complaint from the children (Rajaendram, 2017). The incident reported that parents took bullying as "a rite of passage or that children needs to toughen up as everyone has a part to play against it". So our culture tends to take it as a learning curve for their children instead of an issue to be addressed urgently. 
INTERNATIONAL JOURNAL OF ACADEMIC RESEARCH IN BUSINESS AND SOCIAL SCIENCES

Vol. 10, No. 16, Youth and Community Wellbeing: Issues, Challenges and Opportunities for Empowerment V2. 2020, E-ISSN: 2222-6990 @) 2020 HRMARS

In application of counselling skills and techniques, Western culture may be receptive to a direct or confrontational counselling approach but in Malaysia, we will prefer a subtle counselling approach. Gender preference of counsellors is significantly shown in the Eastern cultures especially in Muslim community where female counsellors will be the preference for female students. Similarly, in-depth understanding of worldview towards other cultures plays a significant part in dealing with clients from different cultures. The learning of worldview is a continuous process and equips school counsellors to be more accommodative and understanding to students from cultures other than their own.

Theoretically, affinity increases when students and school counsellors are from the same culture, religion, language and gender. Therefore, it is important to weight these issues during implementation. Bullying prevention program may be less responsive if it is conducted by female Chinese counsellor in boy schools or Malays counsellor in Chinese schools, to name a few possibilities of the effects.

While demographic considerations are essential in multicultural counselling, cultural consideration based on etic versus emic perspectives; collectivistic versus individualistic society should not be overlooked at all for an effective counselling service to address school bullying issues.

\section{Funding}

This research received no financial support from any funding agency, commercial, or not-for-profit sectors. for the research, authorship, and/or publication of this article.

\section{Declaration of Conflicting Interests}

The author(s) declared no potential conflicts of interest with respect to the research, authorship, and/or publication of this article.

\section{Originality of This Article}

The author(s) acknowledged that this is the original work and has not been submitted to nor published anywhere else.

\section{Reference}

American School Counselor Association. (2003). The ASCA national model: A framework for school counselling programs. Alexandria, VA: Author

American School Counselor Association. (2013). Bullying Prevention Specialist. Alexandria VA: Author. Acuri, M. N. (2017). Counselling Relationship Experiences for K-12 school counsellors who also fulfilled the role of anti-bullying specialist. Journal of School Counselling, 16(5). Retrieved from http://www.jsc.montana.edu/articles/v16n5.pdf

Antwi, H. A., Lulin, Z., Yiranbon, E., Ayegba, J. O., Yebaoh, M.-A., \& Bonsu, E. O. (2014). Diffusion of Medical Innovation: Predicting Patient Attitudes and Intentions to Use Self-Service Technology in Hospitals: Evidence from Chinese Hospitals. International Journal of Academic Research in Public Policy and Governace, 1(1), 1-16.

Austin, M., S., Reynolds, P., G., \& Barnes, L., S. (2016). School leadership and counselors working together to address bullying. Reading Improvement, 53(4), 188-194.

Brown, E. C., Low, S., Smith, B. H., \& Haggerty, K. P. (2011). Outcomes from a school-randomized 
INTERNATIONAL JOURNAL OF ACADEMIC RESEARCH IN BUSINESS AND SOCIAL SCIENCES

Vol. 10, No. 16, Youth and Community Wellbeing: Issues, Challenges and Opportunities for Empowerment V2. 2020, E-ISSN: 2222-6990 @ 2020 HRMARS

controlled trial of Steps to Respect: A Bullying Prevention Program, School Psychology Review, 40(3), pp 423-443.

Cornell, D., \& Huang, F. (2014). Identify victims of bullying: Use of counselors' interview to confirm peers nomination. Professional School Counselling, 18(1), 191- 205.

Didaskalou, E., Skrzypiec, G., Andreou, E., \& Slee, P. (2017). Taking action against victimization: Australia middle school students' experience. Journal of Psychologists and Counsellors in Schools, 27(1), 105-122. doi: 10.1017/jgc.2016.3

Hakam. (2018). Hakam Report: Bullying in Malaysian school. Kuala Lumpur: Author. Retrieved from https://hakam.org.my/wp/download/hakam-report-bullying-in-malaysian-schools30-jan-2018/

Haslee, S. L., Abdullah, N. A., \& Nawi, L. P. L. (2018). Counselling to understand and intervene school bullying. Social Science Learning Education Journal, 3(1).

Jacobsen, K. E., \& Bauman, S. (2007). Bullying in schools: School counsellors' responses to three types of bullying incidents. Professional School Counselling, 11(1), 1-9. doi:10.5330/PSC.n.201011.1

Lund, M. E., Blake, J. J., Ewing, K. H., \& Banks, S. C. (2012). School Counsellors' and School Psychologists' Bullying Prevention and Intervention Strategies: A Look Into Real-World Practices. Journal of School Violence, 11, 246-256.

McCormac, E. M. (2014). An elementary school's 4-year journey: Preventing and responding to bullying. Journal of Professional School Counselling, 18(1), 1-14.

McElearney, A., Adamson, G., Shevlin, M., \& Bunting, B. (2012). Impact Evaluation of a Schoolbased Counselling Intervention in Northern Ireland: Is it Effective for Pupils Who Have Been Bullied? Child Care in Practice, 19(1), 4-22. doi:10.1080/13575279.2012.732557

Midgett, A., Doumas, D. M., \& Johnston, A. D. (2017). Establishing school counsellors as leaders in bullying curriculum delivery: Evaluation of a brief, school-Wide bystander intervention. Professional School Counselling, 21(1), 1-9. doi:10.1080/23727810.2017.1381932

Midgett, A., Doumas, D. M., Sears, D., Lundquist, A., \& Hausheer, R. (2015). A bystander bullying psychoeducation program with middle school students: A preliminary report. The Professional Counselor, 5, 486-500. doi:10.15241/am.5.4.486

Midgett, A. (2016). Bullying: How counsellor can intervene. Counselling Today. Retrieved from https://ct.counselling.org/2016/06/bullying-counsellors-can-intervene/

National Human Rights Society Malaysia, HAKAM. (2018). Report on Bullying in Malaysia School. Retrieved from https://hakam.org.my/wp/2018/01/30/hakam-releases-report-on-bullyinginmalaysian-schools/

NCES. (2018). Repetition and power imbalance in bullying victimization at school. Data point. National Center Education of Statistics, US Department of Education: Author https://nces.ed.gov/pubs2018/2018093.pdf

Olweus, D. (1994). Bullying at school basic facts \& effects of a school-based intervention program. Journal of Child Psychology and Psychiatry, 35, 1171-1190. doi:10.1111/j.14697610.1994.tb01229.x

Olweus, D. (1993). Bullying at school: What we know and what we can do. Oxford, UK. Blackwell Publishing. 
INTERNATIONAL JOURNAL OF ACADEMIC RESEARCH IN BUSINESS AND SOCIAL SCIENCES

Vol. 10, No. 16, Youth and Community Wellbeing: Issues, Challenges and Opportunities for Empowerment V2. 2020, E-ISSN: 2222-6990 @ 2020 HRMARS

Power-Elliott, M., \& Harris, E. G (2012). Guidance counsellor strategies of handling bullying. British Journal of Guidance and Counselling, 40(1), 83-98. doi:10.1080/03069885.2011.646947

Rajaendram, R. (2017, May 28). Dealing with bullying. The Star Online. Retrieved from https://www.thestar.com.my/news/education/2017/05/28/dealing-with-the-bully/

Randa, R., Reyns, W. B., \& Noble, M. (2015). Is Cyberbullying a stand-alone construct? Quantitative analysis to evaluate a $21^{\text {st }}$ century social question. Societies, 5(1), 171-186. doi:10.3390/soc5010171

Salleh, N. M., \& Zainal, K. (2014). Bullying Among Secondary School Students in Malaysia: A Case Study. International Education Studies, 7(13), 184-191. doi:10.5539/ies.v7n13p184

Sudan, A. S. (2016). School Bullying: Victimization in a public primary school in Malaysia. Asian Journal of Management Sciences and Education. 5(3), 120-129.

Suppayah, P. (2016). In Klang primary school, bullying goes beyond child's play. Malay Mail. https://www.malaymail.com/s/1088319/in-klang-primary-school-bullying-goesbeyondchilds-play

Tawalbeh, H. A., Abueita, D. J., Mahasneh, A., \& Shammout, N. (2015). Effectiveness of a Counselling program to improve self-concept and achievement in bully-victims. Review of European Studies, 7(7), 36-45. doi: 10.5539/res.v7n7p.36

Steep rise in school bullying cases. (2017). The Star Online. Kuala Lumpur. Retrieved from https://www.thestar.com.my/news/nation/2017/08/17/steep-rise-in-school-bullying-cases/

Alarming spike in mental health issues, warns MMHA. (2018, Sept 2). The Star Online, Kuala Lumpur: Author Retrieved from https://www.thestar.com.my/news/nation/2018/09/02/alarming spike-in-mental-health-issues warns-mmha/

Wachs, S., Junger, M., Sittichai R. (2015). Traditional, cyber and combined bullying roles: Differences in risky online and offline Activities. Societies, 5(1), 109-135. doi:10.3390/soc5010109

UNESCO. (2017). School Violence and Bullying: Global Status Report. Paris. France: Author

Uzunboylu, H., Baglama, B., Ozer, N., Kucuktamer, T., \& Kuimova, V., M. (2017). Opinion of school counselors about bullying in Turkish high school. Social Behaviour and Personality, 45(6), 1043-1056. doi:10.2224/sbp.6632

Zych, I., Farrington, P., D., Llorent, J., V., \& Ttofi, M., M. (2017). School Bullying in Different Countries: Prevalence, Risk Factors, and Short-Term Outcomes. Protecting Children Against Bullying and Its Consequence. Springer International Publishing. 5-22. NY, USA. 